\title{
Study on the Effects of Packaging and Storage of Himsagar Mango
}

\author{
Laureate R. Hynniewta*, A.K. Banik and L. Jeebit Singh \\ Department of Post-Harvest Technology of Horticultural Crops, Bidhan Chandra Krishi \\ Viswavidyalaya, Mohanpur- 741252, West Bengal, India \\ *Corresponding author
}

\begin{tabular}{|c|c|}
\hline & A B S T R A C T \\
\hline & $\begin{array}{l}\text { The study on effect of packaging and storage condition on the shelf life and chemical } \\
\text { composition of mango cv. Himsagar was carried out at Department of Post-Harvest }\end{array}$ \\
\hline Keywords & $\begin{array}{l}\text { Technology of Horticultural Crops, Faculty of Horticulture, BCKV, Nadia. The fruits of } \\
\text { cultivar were harvested at fully mature but unripe stage and were packed in different }\end{array}$ \\
\hline Fresh Himsagar, & packages (Un-perforated LDPE, Perforated LDPE, Plastic crate, CFB box and Perforated \\
\hline $\begin{array}{l}\text { Cold storage, } \\
\text { Packaging }\end{array}$ & LDPE with CFB box $)$ and placed in cold store $\left(12 \pm 1^{\circ} \mathrm{C} ; 85-90 \% \mathrm{RH}\right)$ whereas control was \\
\hline $\begin{array}{l}\text { Packaging, } \\
\text { Biohemical }\end{array}$ & without packaging under ambient condition. The fruits were examined for biochemical \\
\hline $\begin{array}{l}\text { Bionemical } \\
\text { parameters. }\end{array}$ & \\
\hline Article Info & affected the various chemical constituents of fresh Himsagar mango. There was a gradual \\
\hline $\begin{array}{l}\text { Accepted: } \\
\text { 10 September } 2017 \\
\text { Available Online: } \\
10 \text { October } 2017\end{array}$ & $\begin{array}{l}\text { reducing sugar contents increased during storage. Packing Himsagar mango in LDPE bag } \\
\text { of } 100 \text { gauge thickness with } 1 \% \text { perforation and } 3 \text { ply CFB with } 5 \% \text { perforation at } \\
\text { temperature } 12 \pm 1^{\circ} \mathrm{C} \text { proved to be the best treatment for it recorded more gradual increase } \\
\text { in TSS and total sugar than other treatments up to } 12^{\text {th }} \text { day. It also showed maximum shelf }\end{array}$ \\
\hline & $\begin{array}{l}\text { life and maximum retention of nutritional quality for the cultivar. But, as per sensory } \\
\text { quality the maximum score was attained in CFB box }\left(\mathrm{T}_{4}\right) \text { for Himsagar. }\end{array}$ \\
\hline
\end{tabular}

\section{Introduction}

Mango (Mangifera indica L.) belongs to the order Sapindales in the family Anacardiaceae. India ranks first in mango production contributing over $45.5 \%$ of total production in the world. The total production in India is about 180.02 lakh tons which is $22.1 \%$ of total fruit production. The total area under mango is 25lakh hectare accounting to $35.8 \%$ of total area under fruits with a productivity of 7.2 MT/ha (Anon., 2013).

Due to its adaptability to a wide range of soil and climatic conditions, relatively hardy nature of the tree, the low cost of raising and maintenance and above all the excellent dessert quality of the fruit, cultivation of mango has spread throughout the length and breadth of the country (Singh, 1995).

Himsagar is an early variety of mango. The fruit is medium in size, ovate to ovate-oblique in shape. Peel is medium thick; pulp is firm, cadmium yellow in colour and fibreless. Flavour is delightful, well blended with a tinge of turpentine and taste is very sweet having abundant juice (Srivastava, 1998). 
However, it cannot be stored for a long period of time mainly due to early senescent feature. The fruit develops blackish stains and spoils within a very short period with a maximum storage duration of five to seven days. It most likely fails to tolerate minimum transportation hazards (Siddiqui and Dhua, 2009).

In order to overcome these hurdles there is a necessity to find suitable post-harvest techniques to increase shelf life of mango fruits. Proper temperature management during handling and storage retards ripening and preserves fresh-market quality while extending shelf life (Johnson et al., 1998) as at these temperatures the physiological and biochemical changes within the fruit will be greatly reduced. Good packaging protects fruits from physiological, pathological and physical deterioration in the marketing channels and retains their attractiveness. It also contributes a great deal to quality image of product both in domestic and export markets. Thus, scientific packaging and storage reduces the post-harvest losses and marketing costs substantially, which enables the producer to fetch a competitive price. The current investigation, thus, aims to develop post-harvest management options that can optimize marketing of Himsagar mango without loss of quality.

\section{Materials and Methods}

Fruits of Himsagar cultivar of mango harvested at fully mature but unripe stage were obtained from Horticulture Research Station, BCKV, Nadia district, West Bengal. Harvesting of fruits was done in the early morning hours. The stalks of fruit were cut up to a size of about $1 \mathrm{~cm}$ with secateurs and which they were washed in tap water and then in distilled water containing $50 \mathrm{ppm}$ of chlorine $\left(\mathrm{CaCl}_{2} \mathrm{O}_{2}\right)$, to reduce the microbial load. The fruits were then surface dried under electric fan. The mango fruits were then packed in LDPE, plastic crates, CFB box and
LDPE + CFB box in cold storage at $12 \pm 1^{\circ} \mathrm{C}$ and relative humidity (RH) at $85-95 \%$. Readings were then taken after 3 days interval. Treatment details are given in table 1.

\section{Chemical analysis}

The mango samples were analysed for various constituents. The TSS was determined by refractometer $\left(0-32^{\circ} \mathrm{B}\right)$. Titratable acidity was determined using A.O.A.C. (1990) method. Reducing and total sugars were determined using Lane and Eynon method while beta carotene and ascorbic acid content was estimated according to procedure described by Ranganna (1991).

\section{Sensory evaluation}

1-9 Hedonic scale suggested by Ranganna (1991) was followed.

\section{Results and Discussion}

Packaging and storage had significant effect on various chemical constituents, considered in this study, of fresh Himsagar mango. TSS content of mango fruits gradually increased during storage. The increase in TSS content during storage could be due to losses in water through the respiration and evaporation during storage and concentration of juices (Wills et al., 1980). Cua (1989) also attributed such increase to the conversion of starch into sugar by hydrolysis of the polysaccharide. The maximum TSS was observed in $\mathrm{T}_{5}$ for cultivar (Table 2). The film packagings with CFB box and reduced storage temperature improved the maintenance of TSS could be due to the fact that aging through reduced respiration rate and other undesirable metabolic changes was reduced (Pongener et al., 2011).

The reducing and total sugars of mango fruits that were treated with various treatments 
showed a trend similar to TSS content. The initial increase in total sugars of fruits under different packages might be due to loss of water from the fruits and conversion of polysaccharides and pectic substances into sugars. The increase in total sugars with the storage interval up to 12 days might be due to the hydrolysis of starch, yielding mono-anddisaccharides (Ryall and Pentzer, 1982). Fruit sugar contents (reducing and total sugars) have been reported to increase during the ripening process in storage (Fuchs et al., 1980). Lower sugar content in fruits from polythene packaging treatment was due to lower rate of metabolic processes.

The total titrable acidity of fruits showed a decreasing trend during storage for all the treatments. Such decrease in acidity following storage of fruits has also been reported by Maini et al., (1984). The decrease in acidity during storage could be attributed to the use of organic acids as respiratory substrate during storage and by conversion of acids into sugars. However, maintenance of acidity in polythene packed fruits during storage might be due to the decreased hydrolysis of organic acids and subsequent accumulation of organic acids which were oxidized at a slow rate because of decreased respiration the results are in conformity to similar findings of Venkatesha and Reddy (1994) (Table 3).

There was a decreasing trend of ascorbic acid content in the fruits of all the treatments during the storage period. The loss in ascorbic acid content with the progress of storage period could be attributed to rapid conversion of L-ascorbic acid into dihydro-ascorbic acid in the presence of L-ascorbic acid oxidase (Bashir and Goukh, 2002). Among treatments, ascorbic acid content of samples with perforated LDPE and CFB packaging in Himsagar showed highest retention of ascorbic acid. Barth et al., (1993) attributed the higher ascorbic acid concentration to lower peroxidase activity (an important factor for ascorbic acid oxidation in plant tissue) in package in response to the low $\mathrm{O}_{2}$ and high $\mathrm{CO}_{2}$ concentration inside the polymeric packaging.

Table.1 Treatment details used for packaging of mango

\begin{tabular}{|c|c|}
\hline $\mathbf{T}_{\mathbf{1}}$ & Un-perforated LDPE in cold storage \\
\hline $\mathbf{T}_{\mathbf{2}}$ & Perforated LDPE (1\% perforation) in cold storage \\
\hline $\mathbf{T}_{\mathbf{3}}$ & Plastic crate in cold storage \\
\hline $\mathbf{T}_{\mathbf{4}}$ & Corrugated Fibre Board Box $(5 \%$ ventilation) in cold storage \\
\hline $\mathbf{T}_{\mathbf{5}}$ & LDPE (1\% perforation) + CFB (5\% ventilation) in cold storage. \\
\hline $\mathbf{T}_{\mathbf{6}}$ & without any packaging in ambient temperature \\
\hline
\end{tabular}

Table.2 Effect of packaging and storage on TSS, reducing and total sugars

\begin{tabular}{|c|c|c|c|c|c|c|c|c|c|c|c|c|c|c|c|}
\hline \multirow[b]{2}{*}{ Treatments } & \multicolumn{5}{|c|}{ TSS $\left({ }^{\circ} \mathrm{B}\right)$} & \multicolumn{5}{|c|}{ Reducing sugars (\%) } & \multicolumn{5}{|c|}{ Total sugars $(\%)$} \\
\hline & $\begin{array}{c}0 \\
\text { day }\end{array}$ & $\begin{array}{c}3 \\
\text { day }\end{array}$ & $\begin{array}{c}6 \\
\text { day } \\
\end{array}$ & $\begin{array}{c}9 \\
\text { day }\end{array}$ & $\begin{array}{c}12 \\
\text { day }\end{array}$ & 0 day & 3 day & 6 day & 9 day & $\begin{array}{c}12 \\
\text { day }\end{array}$ & $\begin{array}{c}0 \\
\text { day }\end{array}$ & $\begin{array}{c}3 \\
\text { day }\end{array}$ & 6 day & 9 day & $\begin{array}{c}12 \\
\text { day }\end{array}$ \\
\hline $\mathrm{T}_{1}$ & 5.0 & 8.0 & 12.1 & 15.1 & 15.1 & 1.86 & 2.66 & 4.66 & 5.29 & 5.30 & 3.55 & 4.62 & 7.20 & 9.01 & 9.12 \\
\hline $\mathrm{T}_{2}$ & 5.2 & 7.1 & 12.0 & 14.8 & 15.1 & 3.48 & 2.44 & 4.40 & 5.42 & 5.56 & 3.62 & 4.20 & 7.28 & 9.05 & 9.60 \\
\hline $\mathrm{T}_{3}$ & 4.9 & 6.0 & 10.0 & 14.1 & 14.1 & 3.38 & 2.01 & 4.07 & 5.23 & 5.11 & 3.44 & 3.61 & 6.10 & 8.40 & 8.46 \\
\hline $\mathrm{T}_{4}$ & 5.2 & 9.1 & 13.0 & 16.0 & 16.2 & 3.42 & 2.80 & 4.81 & 5.67 & 5.52 & 3.62 & 5.40 & 7.85 & 9.67 & 9.63 \\
\hline $\mathrm{T}_{5}$ & 5.2 & 8.0 & 17.0 & 18.0 & 16.9 & 1.72 & 3.69 & 5.68 & 5.87 & 5.76 & 3.61 & 4.87 & 10.23 & 10.89 & 10.29 \\
\hline $\mathrm{T}_{6}$ & 5.1 & 11.1 & 14.0 & 14.1 & 14.1 & 1.96 & 3.24 & 5.58 & 5.58 & 5.59 & 3.50 & 6.60 & 8.40 & 8.47 & 8.54 \\
\hline $\operatorname{SEm}( \pm)$ & 0.09 & 0.23 & 0.27 & 0.19 & 0.26 & 0.04 & 0.06 & 0.10 & 0.09 & 0.09 & 0.05 & 0.14 & 0.12 & 0.17 & 0.14 \\
\hline C.D 5\% & $\mathrm{NS}$ & 0.72 & 0.82 & 0.75 & 0.80 & 0.13 & 0.25 & 0.31 & 0.27 & 0.28 & NS & 0.67 & 0.89 & 0.53 & 0.73 \\
\hline
\end{tabular}


Table.3 Effect of packaging and storage on acidity, ascorbic acid and beta carotene

\begin{tabular}{|c|c|c|c|c|c|c|c|c|c|c|c|c|c|c|c|}
\hline \multirow[b]{2}{*}{ Treatments } & \multicolumn{5}{|c|}{ Total acidity (\%) } & \multicolumn{5}{|c|}{ Ascorbic acid (mg/100gm fruit) } & \multicolumn{5}{|c|}{ Beta Carotene (mg/ 100gm fruit) } \\
\hline & $\begin{array}{c}0 \\
\text { day }\end{array}$ & 3 day & 6 day & 9 day & $\begin{array}{c}12 \\
\text { day }\end{array}$ & 0 day & 3 day & 6 day & 9 day & $\begin{array}{c}12 \\
\text { day }\end{array}$ & 0 day & 3 day & 6 day & 9 day & 12 day \\
\hline $\mathrm{T}_{1}$ & 1.16 & 1.037 & 0.701 & 0.517 & 0.400 & 44.12 & 35.00 & 32.39 & 28.43 & 19.64 & 689 & 1854 & 4168 & 7510 & 7577 \\
\hline $\mathrm{T}_{2}$ & 1.16 & 1.025 & 0.711 & 0.602 & 0.304 & 44.93 & 37.63 & 32.99 & 26.82 & 20.46 & 689 & 1707 & 3957 & 7415 & 9403 \\
\hline$T_{3}$ & 1.16 & 0.910 & 0.615 & 0.515 & 0.400 & 44.86 & 33.26 & 30.62 & 23.04 & 17.52 & 692 & 1597 & 3587 & 6367 & 9318 \\
\hline $\mathrm{T}_{4}$ & 1.16 & 0.902 & 0.619 & 0.616 & 0.408 & 45.09 & 36.94 & 33.09 & 27.73 & 19.25 & 688 & 1756 & 3710 & 7289 & 9510 \\
\hline $\mathrm{T}_{5}$ & 1.66 & 1.026 & 0.704 & 0.411 & 0.400 & 44.14 & 38.21 & 39.98 & 31.55 & 26.75 & 689 & 1902 & 4545 & 7598 & 9913 \\
\hline $\mathrm{T}_{6}$ & 1.17 & 0.915 & 0.608 & 0.430 & 0.299 & 43.80 & 31.59 & 26.11 & 24.01 & 22.11 & 689 & 2456 & 7578 & 7908 & 7915 \\
\hline SEm ( \pm$)$ & 0.01 & 0.021 & 0.013 & 0.012 & 0.008 & 0.80 & 0.93 & 0.91 & 0.66 & 0.52 & 10.39 & 48.31 & 96.74 & 130.20 & 55.88 \\
\hline C.D 5\% & NS & 0.065 & 0.039 & 0.036 & 0.024 & NS & 2.86 & 2.81 & 3.04 & 2.60 & NS & 148.86 & 298.10 & 301.19 & 272.17 \\
\hline
\end{tabular}

Table.4 Sensory score for Himsagar

\begin{tabular}{|c|c|c|c|c|c|c|c|c|c|}
\hline \multirow{2}{*}{ Treatments } & \multicolumn{3}{|c|}{ Colour } & \multicolumn{3}{c|}{ Flavour } & \multicolumn{3}{c|}{ Overall } \\
\cline { 2 - 10 } & 6 day & 9 day & 12 day & 6 day & 9 day & 12 day & 6 day & 9 day & 12 day \\
\hline $\mathrm{T}_{1}$ & 5.8 & 6.6 & 1.0 & 4.0 & 6.8 & 1.2 & 9.8 & 13.4 & 2.2 \\
\hline $\mathrm{T}_{2}$ & 6.2 & 6.8 & 7.6 & 6.2 & 7.0 & 8.4 & 12.4 & 13.8 & 16 \\
\hline $\mathrm{T}_{3}$ & 6.8 & 7.1 & 7.8 & 6.1 & 6.8 & 7.8 & 12.9 & 13.9 & 15.6 \\
\hline $\mathrm{T}_{4}$ & 6.9 & 7.5 & 8.6 & 5.3 & 7.3 & 8.6 & 12.2 & 14.8 & 17.2 \\
\hline $\mathrm{T}_{5}$ & 7.1 & 7.8 & 8.5 & 4.4 & 7.4 & 7.7 & 11.5 & 15.2 & 16.2 \\
\hline $\mathrm{T}_{6}$ & 8.2 & 1.1 & 1.2 & 8.4 & 1.0 & 1.0 & 16.6 & 2.1 & 2.2 \\
\hline SEm $( \pm)$ & 0.67 & 0.41 & 0.71 & 0.73 & 0.51 & 0.42 & 1.4 & 0.92 & 1.13 \\
\hline C.D 5\% & 0.002 & 0.002 & 0.003 & 0.001 & 0.001 & 0.003 & 0.003 & 0.003 & 0.006 \\
\hline
\end{tabular}

It was observed that the carotenoids content of the pulp increased steadily as the storage period increased. The increase in the carotenoids of the pulp maybe attributed to the concurrent increase of pigment synthesis in the pulp as the storage advanced and does not just involve a simple unmasking of carotenoids (Kays, 1991; Fennema 1996). Similar result was reported in mango cultivar Dashehari (Periyathambi, 2013) packaging and storage.

Among the different treatments CFB box in cold store received the highest scoring for sensory evaluation in Himsagar. This is mainly due to the fact that treatment effectively reduced physiological loss in weight and spoilage loss and also effectively retained firmness, colour change and nutrient loss of fruits during storage. This finding is also supported by Sharma and Singh (2010) (Table 4).

In Himsagar $\mathrm{T}_{1}$ (Un-perforated plastic) recorded the least sensory which can be mainly attributed to the low fruit quality and strong aldehydic flavour of fruit that render it unacceptable for consumption (Lakshmana et al., 2013).

Based on the above investigation it can thus be concluded that mango cultivar 'Himsagar' can be packed in LDPE bags of 100-gauge thickness with $1 \%$ perforation and CFB with $5 \%$ perforation at a temperature of $12 \pm 1{ }^{\circ} \mathrm{C}$ for up to 12 days with minimal loss in biochemical quality and acceptable eating quality.

\section{References}

A.O.A.C. 1990. Official Methods of Analysis. Association of Official Analytical Chemists, Washington DC

Anonymous, 2012-13. Website: nhb.gov.in/area-pro/ database-2013.

Barth, M.M., E.L. Kerbel, S. Broussard and S.J. Schmidt. 1993. Modified atmosphere packaging protects market quality in broccoli spears under ambient temperature storage. J. Food Sci., 58(5): 1070-1072. 
Bashir, A.H., and Goukh, A. A. 2002. Compositional changes during guava fruit ripening. Food Chem., 80 (4): 557563.

Cua, A.U., 1989. Ethylene biosynthesis in Carabao mango fruit (Mangifera indica L.) during maturation and ripening. M.Sc. Thesis, University of the Philippines at Los Banos, College, Laguna, Philippines.

Fennema, O. R., 1996. In: Food Chemistry, 3rd Ed., Marcel Dekker Inc, New York.

Fuchs, Y., Pesis, E. and Zauberman, G. 1980. Changes in amylase activity, starch and sugars contents in mango fruit pulp. Sci. Hort., 13: 155-160

Johnson, P.R., and Ecker, J.R. 1998. The ethylene gas signal transduction pathway: a molecular perspective. Ann. Rev. Genet., 32: 227-254.

Kays, S.J., 1991. In: Post harvest physiology of perishable plant products, Van Nostrand Reinhold, New York.

Lakshmana, Ramesha, Y. S., and Janardhan, G. 2013. Effect of polythene bag storage on shelflife and quality of wax apple (Syzygium samarangense). Int. J. Agric. Sci. Vet. Med. 1(4): 16-21.

Maini, S.B., Diwan, B., Lal, B.B. and Anand, J.C. 1984. Comparative performance of packing in trays and conventional pack during transit. J. Food Sci. Technol. 20: 409-10.

Periyathambi, R., Navprem, S., Kaur H. and Jawandha, S.K. 2013. Effect of postharvest treatments on the ambient storage of mango cv. Dashehari. Progressive Hort. 45 (1): 104-109.
Pongener, A., Mahajan, B.V.C. and Singh, H. 2011. Effect of different packaging films on storage life and quality of peach fruits under cold storage conditions. Indian J. Hort., 68(2): 240245.

Ranganna, S., 1991. Manual of analysis of fruit and vegetable products. 2nd Ed., Tata Mc Graw Hill Pub. Co. Ltd., New Delhi.

Ryall, A.L., and Pentzer, W.T. 1982. Handling, transportation and storage of fruits and vegetables. AVI Pub. Co. Inc., Westport.

Siddiqui, M.W., and Dhua, R.S. 2009. Standardization of ethrel treatment for inducing ripening of mango var. Himsagar. Proceedings of International Conference on Horticulture (ICH2009), Bangalore. pp. 1641-1648.

Singh, S.P., 1995. Mango. In: Commercial Fruits, Kalyani Publishers, Ludhiana. pp. 30-71.

Srivastava, R.P., 1998. Mango cultivation. In: Mango cultivar. Published by International Book Distribution, New Delhi. p. 54.

Venkatesha, M., and Reddy, T.V. 1994. Extension of storage life of guava (Psidium guajava L.) fruits. Indian Food Packer, 48: 5-10.

Wills, R.B.H., Cambridge, P.A. and Scott, K.J. 1980. Use of flesh firmness and other objective tests to determine consumer acceptability of Delicious apples. Aust. J. Exp. Agric. Anim. Husb.

\section{How to cite this article:}

Laureate R. Hynniewta, A.K. Banik and Jeebit Singh, L. 2017. Study on the Effects of Packaging and Storage of Himsagar Mango. Int.J.Curr.Microbiol.App.Sci. 6(10): 1044-1048. doi: https://doi.org/10.20546/ijcmas.2017.610.126 